\title{
ANALISA FAKTOR PENENTU KEPUASAN KERJA PERAWAT PELAKSANA DI INSTALASI RAWAT INAP RSUD LANGSA
}

\author{
Dian Ariani $^{{ }^{*}}$, Tarsyad Nugraha $^{2}$, Imam Muhammad $^{3}$ \\ ${ }^{1,2,3}$ Institut Kesehatan Helvetia, Medan \\ email; antoarunraja@gmail.com

\section{Analysis Of Determining Factors Of Work Satisfaction For The Nurses In The Inpatient Installation Of Rsud Langsa}

\begin{abstract}
Upgrading and stabilizing the characters of the nurses has recently invented a demand of the society, either in the health services generally or in nursing particularly. An advanced job satisfaction is determined in a standardin which the organization has been implementing abehavioral management effectively (4). This research applied the dependent variable that refers to a job satisfaction and independent variables that refers to leadership style, motivation, supervision and work environment. This research applied an analytic survey with a cross sectional study design. The population of this research requiredthe entire nurses in the Inpatient Room of RSUD Langsa, meanwhile there wereabout 73 respondents asan obvious sample of this research andthe sampling had applied a technic namely Proportional Stratified Random Sampling. The conclusion of the research stated that leadership style and job satisfaction of the nurses are related to one another in RSUD Langsa with a p-value of 0.001 ( $p$ $<0.05)$, there is a correlation between motivation and job satisfaction of the nurses in RSUD LANGSA with a pvalue of 0,000 ( $p<0,05)$, there is a correlation between supervision and job satisfaction of the nurses in RSUD LANGSA with a p-value of 0,000 ( $<<0.05)$ and there is a correlation between the kerha environment and job satisfaction of the nurses in RSUD LANGSA with a p-value of $0.003(p<0,05)$. Based on the multivariate analysis revealed that among the four independent variables that influence the dependent variable (job satisfaction) the most is work motivation and supervision. To the chief of nursing in RSUD LANGSA, in order to reevaluate to the entire supervisors comprehensively and enhancing a supervision towards a standard achivement of working, conducting a cordiall relationship with the employees and offering a proper reward in whichensuring the salaries equally should have been attempted in order to motivate the nurses in working profesionally.
\end{abstract}

Keywords: Job Satisfaction, Leadership Style, Motivation, Supervision and Work Environment.

\begin{abstract}
Abstrak
Peningkatan dan pemantapan peran bagi perawat akhir-akhir ini menjadi tuntutan masyarakat, baik pada layanan kesehatan pada umumnya maupun keperawatan pada khususnya.Kepuasan kerja yang tinggi merupakan tanda bahwa organisasi telah melakukan manajemen perilaku yang efektif (4).Penelitian ini bertujuan untuk mengetahui faktor penentu kepuasan kerja perawat pelaksana di Instalasi Rawat Inap RSUD Kota Langsa tahun 2019. Penelitian ini menggunakan variabel dependen yaitu kepuasan kerja dan variabel independen yaitu gaya kepemimpinan, motivasi, supervisi dan lingkungan kerja. Penelitian ini survey analitik dengan desain penelitian adalah cross sectional. Populasi penelitian ini adalah seluruh perawat pelaksana yang ada di Ruang Rawat Inap RSUD Kota Langsa.Sampel dalam penelitian ini berjumlah 73 responden.Teknik pengambilan sampel menggunakan teknik Proportional Stratified Random Sampling. Kesimpulan dari hasil penelitian bahwa ada hubungan gaya kepemimpinan dengan kepuasan kerja perawat pelaksana di RSUD Langsa dengan p-value 0,001 ( $p<0,05)$, ada hubungan motivasi dengan kepuasan kerja perawat pelaksana di RSUD Langsa dengan p-value $0,000(p<0,05)$, ada hubungan supervisi dengan kepuasan kerja perawat pelaksana di RSUD Langsa dengan p-value $0,000(p<0,05)$ dan ada hubungan lingkungan kerja dengan kepuasan kerja perawat pelaksana di RSUD Langsa dengan p-value 0,003 $(\mathrm{p}<0,05)$. Berdasarkan analisa multivariat ditemukan bahwa antara keempat variabel bebas yang paling mempengaruhi terhadap variabel dependenkepuasan kerjaadalah motivasi kerja dan supervisi.
\end{abstract}

Kata Kunci: Kepuasan Kerja, Gaya Kepemimpinan, Motivasi, Supervisi dan Lingkungan Kerja. 


\section{PENDAHULUAN}

Tujuan pembangunan kesehatan adalah tercapainya hidup sehat bagi setiap penduduk agar dapat terwujud nya derajat kesehatan yang optimal, untuk itu diselenggarakan upaya kesehatan yang menyeluruh, merata, terpadu serta bermutu bagi seluruh lapisan masyarakat.Rumah sakit sebagai salah satu unit pelayanan kesehatan masyarakat merupakan salah satu bagian integral dari pelayanan kesehatan secara keseluruhan yang harus berjalan terpadu untuk mencapai tujuan pembangunan, yaitu terciptanya kesejahteraan masyarakat. ${ }^{(1)}$

Pelayanan keperawatan menjadi faktor penentu keberhasilan pelayanan kesehatan di rumah sakit, karena hampir di setiap negara hingga $80 \%$ pelayanan kesehatan diberikan oleh perawat.sebanyak $40 \%$ pemberi pelayanan kesehatan di Indonesia adalah tenaga keperawatan. Tenaga keperawatan memberikan kontribusi yang cukup besar terhadap pelayanan yang diberikan oleh sebuah Rumah Sakit, karena pelayanan keperawatan memberikan pelayanan konstan dan berkesinambungan dengan pelanggan yaitu pasien dan keluarganya selama 24 jam sehari dan 7 hari dalam seminggu. Oleh karena itu pelayanan tenaga keperawatan menentukan mutu dan membentuk image rumah sakit.

Salah satu indikator mutu pelayanan rumah sakit yaitu tingkat kepuasan kepada pelanggan baik internal maupun eksternal.Pelanggan eksternal rumah sakit yaitu pasien dan keluarganya sedangkan pelanggan internal rumah sakit terdiri dari beberapa profesi yang diantaranya adalah perawat. ${ }^{(2)}$

Perawat adalah suatu profesi yang difokuskan pada perawatan individu, keluarga dan masyarakat sehingga mereka dapat mencapai, mempertahankan dan memulihkan kesehatan yang optimal dan kualitas hidup dari lahir sampai mati.Perawat memegang tanggung jawab dalam memenuhi kebutuhan dasar klien.Perawat diharapkan memandang klien sebagai makhluk unik yang komprehensif dalam memberikan perawatan.

Peningkatan dan pemantapan peran bagi perawat akhir-akhir ini menjadi tuntutan masyarakat, baik pada layanan kesehatan pada umumnya maupun keperawatan pada khususnya. Kinerja perawat dapat terukur berdasarkan beberapa indikator antara lain kuantitas hasil kerja, kualitas hasil kerja, efisiensi dalam melaksanakan tugas, disiplin kerja, inisiatif, ketelitian, kepemimpinan, kejujuran dan kreatifitas. Tuntutan dan kebutuhan asuhan keperawatan yang berkualitas di masa depan merupakan tantangan yang harus dipersiapkan secara benar-benar dan ditangani secara mendasar, terarah dan sungguh-sungguh dari rumah sakit

Perawat punya peran penting sebagai pelaksana tindakan medis, mengawasi atau mengontrol keadaan dan perkembangan pasien yang sedang dalam perawatan. Perawat adalah orang yang mengasuh dan merawat orang lain yang mengalami masalah kesehatan. Perawar selain memiliki kemampuan intelektual, interpersonal, dan teknikal, juga harus mempunyai otonomi dan bersedia 
menanggung resiko, bertanggung jawab, dan bertanggung gugat terhadap semua tindakkan yang dilakukannya.Perawat dalam bekerja harus profesional.Dengan pekerjaannya itu diharapkan perawat bisa memperoleh kepuasan kerja. (3)

Kepuasan kerja adalah sikap umum seseorang individu terhadap pekerjaan yang dilakukannya.Seseorang dengan tingkat kepuasan kerja tinggi menunjukkan sikap yang positif terhadap pekerjaannya, sedangkan seseorang yang tidak puas dengan pekerjaannya menunjukkan sikap yang negatif terhadap pekerjaannya.Kepuasan kerja yang tinggi merupakan tanda bahwa organisasi telah melakukan manajemen perilaku yang efektif ${ }^{(4)}$.

Dalam proses kepemimpinan, motivasi merupakan sesuatu esensial dalam kepemimpinan, karena pemimpin adalah memotivasi. Kepemimpinan mempunai kaitan yang erat dengan motivasi, sebab keberhasilan seorang pemimpin dalam menggerakkan orang lain daam mencapai tujuan yang telah ditetapkan sangat bergantung kepada kewibawaan, dan juga pemimpin itu dalam menciptakan motivasi didalam diri setiap orang bawahan, kolega, maupun atasan pimpinan sendiri dengan demikian dapat dimengerti bahwa motivasi merupakan masalah yang sangat penting dalam setiap kelompok orang yang bekerja sama dalam pencapaian tujuan tertentu. Sehinggadapat dikatakan, bahwa keberhasilan seorang pemimpin dalam menggerakkan orang lain dapat dilihat bila mampu menciptakan motivasi sesuai dengan keadaan bawahan dan pekerjaanya. ${ }^{(5)}$.

Supervisi yang diberikan oleh supervisor atu atasan merupakan faktor yang dapat menyebabkan kepuasan kerja. Begitupun hasil penelitian yang dilakukan oleh Syahrir yang menyimpulkan bahwa faktor lain yang dapat mempengaruhi kepuasan kerja perawat adalah supervisi. Supervisi yang diberikan oleh supervisor atau atasan merupakan faktor yang dapat menyebabkan kepuasan kerja. Supervisi adalah proses pengamatan dari pelaksanaan seluruh kegiatan organisasi untuk menjamin agar semua pekerjaan yang sedang dilakukan berjalan sesuai dengan rencana yang telah ditetapkan. Sedangkan supervisi manajemen keperawatan merupakan salah satu jenis kegiatan pengamatan secara seksama sebagai sarana mengetahui kesalahan awal di semua aspek untuk langsung diperbaiki atau dimodifikasi agar berjalan sesuai dengan ketentuan/pedoman pekerjaan yang telah disepakati bersama ${ }^{(3)}$.

Hasil penelitian yang dilakukan oleh Putri, Striatmi \& Fatmasari (2018), mengenai faktor-faktor yang berhubungan dengan kepuasan kerja perawat rawat inap Rumah Sakit Umum Daerah Tugurejo Semarang yang menyimpulkan bahwa dan hubungan supervisi dengan kepuasan kerja perawat rawat inap RSUD Tugurejo Semarang (p value 0,000) (7).

Sejalan dengan penelitian yang dilakukan oleh Kontesa (2014), mengenai hubungan gaya kepemimpinan kepala ruangan dengan motivasi kerja perawat di Ruang Rawat Inap Rumah Sakit Umum Dr. Rasidin Padang 
yang menyimpulkan bahwa ada hubungan gaya kepemimpinan kepala ruangan dengan motivasi kerja perawat ${ }^{(5)}$.

Penelitian ini juga didukung oleh penelitian yang dilakukan oleh Indriono \& Zaenudin (2015), mengenai hubungan motivasi kerja perawat dengan kepuasan kerja perawat di Instalasi Rawat Inap Badan Rumah Sakit Umum Daerah Kabupaten Batang yang menyimpulkan bahwa ada hubungan motivasi kerja perawat dengan kepuasan kerja perawat dengan $p$-value $0,029(\mathrm{p}<0,05)^{(1)}$.

Hasil penelitian yang dilakukan oleh Pratiwi mengenai hubungan lingkungan kerja dengan kepuasan kerja perawat pelaksana di Ruang Bangsal Rawat Inap Rsud Sunan Kalijaga Kabupaten Demak yang menunjukkan adanya pengaruh kualitas keperawatan $\quad(\mathrm{p}=0,022 ; \quad \operatorname{Exp} \quad \mathrm{B}=5,768)$, otonomi $\quad(p=0,020 ; \quad \operatorname{Exp} \quad \mathrm{B}=6,023) \quad$ dan pengembangan profesional $(p=0,002$; Exp $\mathrm{B}=$ 12,082) secara bersama-sama terhadap kepuasan kerja perawat pelaksana ${ }^{(8)}$.

RSUD Langsa merupakan suatu institusi pelayanan kesehatan masyarakat Kota Langsa yang baru-baru ini menimbulkan isu-isu yang kurang baik mengenai birokrasi di lingkungan rumah sakit tersebut salah satunya adalah mengenai pembagian uang jasa dan penerimaan tenaga kontrak yang menimbulkan penolakan dari beberapa pejabat serta karyawan di instansi tersebut. Pada akhir tahun 2018 lalu kegiatan unjuk rasa digelar oleh beberapa karyawan RSUD Langsa sebagai penolakan atas birokrasi yang telah ditetapkan, hal ini merupakan salah satu bentuk ketidakpuasan karyawan dalam bekerja di RSUD Langsa.

Hasil survey awal yang penulis lakukan dengan melakukan penyebaran kuesioner kepada 10 orang perawat ditemukan bahwa terdapat beberapa perawat yang tidak puas bekerja sebagai perawat pelaksana di Ruang Rawat Inap RSUD Kota Langsa diantaranya 7 perawat mengatakan tidak puas, untuk gaya kepemimpinan sebanyak 7 menerapkan gaya otoriter dan 3 demokratis, ditinjau dari aspek motivasi ditemukan bahwa sebanyak 7 perawat tidak termotivasi dan sebanyak sebanyak 6 perawat tidak puas dengan supervisi.

\section{BAHAN DAN METODE}

Penelitian ini dilakukan menggunakan survei analitik yaitu penelitian yang mencoba menggali bagaimana dan mengapa fenomena itu terjadi.jenis penelitian ini adalah penelitian yang menggunakan Cross Sectional merupakan penelitian atau penelahan hubungan antara dua variabel pada suatu situasi atau sekelompok subjek, yaitu untuk mengetahui faktor penentu kepuasan kerja perawat pelaksana. Populasi dalam penelitian ini adalah seluruh perawat pelaksana di Ruang Rawat Inap RSUD Langsa, sampel sebanyak 73 orang.Teknik pengambilan sampel secara Proportional Stratified Random Sampling.

Alat yang digunakan untuk pengambilan data adalah kuesioner yang terdiri dari 82 item pertanyaan.Kuesioner ini merupakan kuesioner tertutup sehingga responden tinggal memilih salah satu pilihan jawaban yang sudah disediakan. 
Analisis data menggunakan program komputer, analisis univariat untuk mengetahui fistribuis frekuensi masing-masing variabel, analisa bivaiat menggunakan uji chi-square.

\section{HASIL}

Analisa Univariat : Berdasarkan tabel di atas menunjukkan bahwa dari 73 responden ditemukan bahwa mayoritas perawat tidak puas dalam bekerja sebanyak 41 responden
$(43,8 \%)$, mayoritas menerapkan gaya kepemimpinan demokratis sebanyak 32 responden $(43,8 \%)$ dan minoritas menerapkan gaya kepemimpinan bebas tindak sebanyak 2 responden $(2,7 \%)$, mayoritas memiliki motivasi kerja yang positif sebanyak 41 responden $(56,25 \%)$, mayoritas mendapatkan supervisi baik sebanyak 50 responden $(68,5 \%)$ dan mayoritas memiliki lingkungan kerja yang baik sebanyak 47 responden $(64,4 \%)$.

Tabel 4.1

Distribusi Frekuensi Kepuasan Kerja, Gaya Kepemimpinan, Motivasi Kerja, Supervisi dan Lingkungan Kerja Perawat Pelaksana di uang Rawat Inap RSUD Langsa

Tahun 2019

\begin{tabular}{ccc}
\hline Kepuasan Kerja & Frekuensi & Persentase (\%) \\
\hline Puas & 41 & 56,2 \\
Tidak Puas & 32 & 43,8 \\
Gaya Kepemimpinan & & \\
Demokratis & 32 & 43,8 \\
Partisipatif & 15 & 20,5 \\
Motivasi & 24 & 32,9 \\
Supervisi & 2 & 2,7 \\
Motivasi Kerja & & \\
Positif & 41 & 56,2 \\
Negatif & 32 & 43,8 \\
Supervisi & & 68,5 \\
Baik & 50 & 31,5 \\
Tidak Baik & 23 & 64,4 \\
Lingkungan Kerja & & 35,6 \\
Baik & 47 & \\
Kurang Baik & 26 & \\
\hline
\end{tabular}

\section{Analisa Bivariat :}

Berdasarkan tabel diatas hasil analisa bivariat menggunakan uji chi-square menyimpulkan bahwa ada hubungan gaya kepemimpinan, motivasi supervisi dan lingkungan kerha dengan kepuasan kerja perawat pelaksana di RSUD 
Tabel 2

Hubungan Gaya Kepemimpinan, Motivasi Kerja, Motivasi dan Lingkungan Kerja dengan Kepuasan Kerja Perawat Pelaksana di Instalasi Rawat Inap RSUD Langsa

\begin{tabular}{|c|c|c|c|c|c|c|c|}
\hline \multirow{3}{*}{ Variabel } & \multicolumn{4}{|c|}{ Kepuasan Kerja } & \multirow{2}{*}{\multicolumn{2}{|c|}{$\begin{array}{l}\text { Jumlah } \\
\text { Puas }\end{array}$}} & \multirow{3}{*}{ P-Value } \\
\hline & \multicolumn{2}{|c|}{ Puas } & \multicolumn{2}{|c|}{ Tidak Puas } & & & \\
\hline & $\mathbf{f}$ & $\%$ & $\mathbf{f}$ & $\%$ & $\mathbf{F}$ & $\%$ & \\
\hline \multicolumn{8}{|l|}{ Gaya Kepemimpinan } \\
\hline Demokratis & 25 & 34,2 & 7 & 9,6 & 32 & 100 & \multirow{4}{*}{0,001} \\
\hline Partisipatif & 11 & 15,1 & 4 & 5,5 & 15 & 100 & \\
\hline Otoriter & 4 & 5,5 & 20 & 27,4 & 24 & 100 & \\
\hline Bebas Tindak & 1 & 1,4 & 1 & 1,4 & 2 & 100 & \\
\hline \multicolumn{8}{|l|}{ Motivasi } \\
\hline Positif & 38 & 52,1 & 3 & 4,1 & 41 & 56,2 & \multirow[t]{2}{*}{0,000} \\
\hline Negatif & 3 & 4,1 & 29 & 39,7 & 32 & 43,8 & \\
\hline \multicolumn{8}{|l|}{ Supervisi } \\
\hline Baik & 41 & 56,2 & 9 & 12,3 & 50 & 68,5 & \multirow[t]{2}{*}{0,000} \\
\hline Tidak Baik & 0 & 0 & 23 & 31,5 & 23 & 31,5 & \\
\hline \multicolumn{8}{|c|}{ Lingkungan Kerja } \\
\hline Baik & 39 & 53,4 & 8 & 11 & 47 & 64,4 & \multirow[t]{2}{*}{0,000} \\
\hline Kurang Baik & 2 & 2,7 & 24 & 32,9 & 26 & 35,6 & \\
\hline
\end{tabular}

Tabel 3.

Analisa Multivariat Faktor Penentu Kepuasan Kerja Perawat Pelaksana di Instalasi Rawat Inap RSUD Langsa

\begin{tabular}{lcccc}
\hline \multicolumn{1}{c}{ Variabel } & \multirow{2}{*}{ Sig } & Exp (B) & \multicolumn{2}{c}{ 95\% c FOR Exp (B) } \\
Lower & Upper \\
\hline Gaya Kepemimpinan & 0,452 & 250388 & 0,000 & - \\
Motivasi Kerja & 0,000 & 0.052 & 0,004 & 0.634 \\
Supervisi & 0,057 & 0.000 & 0,000 & - \\
Lingkungan Kerja & 0,972 & 0,110 & 0,005 & 2,320 \\
Constant & 0,043 & 0,003 & & \\
\hline
\end{tabular}

\section{PEMBAHASAN}

\section{Kepuasan Kerja Perawat Pelaksana}

: Hasil penelitian menunjukkan bahwa dari 73 perawat pelaksana ditemukan bahwa mayoritas perawat merasa puas dalam bekerja sebanyak 41 responden $(56,2 \%)$.

Hasil penelitian ini sesuai dengan penelitian yang dilakukan oleh Fahrurozi tentang hubungan gaya kepemimpinan kepala ruangan dengan kepuasan kerja perawat pelaksana di Puskesmas Langsa Lama. Hasil analisis univariat, didapat bahwa pada kepuasan kerja perawat $85,7 \%$ puas dan $14,3 \%$ tidak puas ${ }^{(32)}$.

Hasil penelitian ini tidak sejalan dengan penelitian tentang kepuasan kerja di Suatu Rumah Sakit Swasta di Jakarta di 
dapatkan hasil bahwa $10,1 \%$ perawat yang tidak puas Lenny Rosbi Rimbun. Hasil penelitian tentang beberapa faktor yang berhubungan dengan kepuasan kerja perawat di Rumah Sakit Umum Daerah Ambarawa Jawa Tengah menunjukkan bahwa tingkat kekurang puasan perawat masih tinggi yaitu $24 \%$ merasa tidak puas ${ }^{(33) .}$

Penelitian lain yang dilakukan Sean P. Clarke, pada 1.783 perawat di Amerika Serikat dan Kanada yang rata-rata adalah perawat yang sudah bekerja di rumah sakit selama lebih dari 15 tahun hasilnya menyatakan bahwa 23\% cukup tidak puas, dan $9 \%$ sangat tidak puas. Aspek kepemimpinan perawat menempati ketidakpuasan yang paling besar yaitu 57\% perawat tidak puas dengan gaya kepemimpinan yang ada ${ }^{(34)}$

Menurut Hasibuan, kepuasan kerja akan memberikan efek terhadap beberapa aspek, yaitu: kinerja, kemangkiran dan keterlambatan, pindah kerja, komitmen terhadap organisasi. Individu yang merasa puas akan pekerjaan nya otomatis akan meningkatkan produktifitasnya dalam bekerja, baik itu ketepatan dalam kehadiran jam kerja, komitmen untuk tetap mempertahankan pekerjaan di perusahaan tersebut sehingga termotivasi untuk tidak pindah kerja ${ }^{(35)}$.

Kepuasan kerja merupakan suatu bentuk sikap emosional yang menyenangkan dan mencintai pekerjaan yang digelutinya. Kepuasan kerja dalam pekerjaan ialah kepuasan kerja yang dapat dinikmati dalam pekerjaan dengan mendapatkan hasil dari pencapaian tujuan kerja, penempatan, perlakuan, dan suasana lingkungan kerja yang baik. Karyawan yang dapat menikmati kepuasan kerja dalam pekerjaan ini, akan memilih untuk lebih mengutamakan pekerjaannya daripada balas jasa/ upah yang ia dapatkan dari pekerjaan tersebut. Karyawan akan merasa lebih puas apabila balas jasanya sebanding dengan hasil kerja yang dilakukan (11).

Kepuasan kerja difungsikan untuk dapat meningkatkan semangat kerja karyawan, meningkatkan produktivitas, menurunkan tingkat absensi, meningkatkan loyalitas karyawan dan mempertahankan karyawan untuk tetap bekerja di suatu perusahaan. Karyawan yang mendapatkan kepuasan kerjanya ialah karyawan yang memiliki tingkat kehadiran dan perputaran kerja yang baik, pasif dalam serikat kerja, dan memiliki prestasi kerja yang lebih baik dari karyawan lainnya. Sedangkan karyawan yang tidak memperoleh kepuasan kerja akan memberikan dampak bagi perusahaan berupa kemangkiran karyawan, perputaran kerja, kelambanan dalam menyelesaikan pekerjaan, pengunduran diri lebih dini, aktif dalam serikat kerja, terganggu kesehatan fisik dan mental karyawannya $^{(10)}$.

$$
\text { Peneliti berasumsi bahwa sebagian }
$$
besar perawat sudah merasakan kepuasan kerja namun perawat yang tidak merasakan kepuasan kerja juga tergolong tinggi yaitu mencapai $56,2 \%$ hal ini dapat memberikan dampak terhadap buruknya kualitas pelayanan yang diberikan perawat pelaksana yang merasa tidak puas dalam menjalankan pekerjaanya 
sebagai perawat pelaksana di Ruang Rawat Inap RSUD Kota Langsa, ketidakpuasan yang dirasakan perawat tercermin pada jawaban responden yang sebagian besar mengatakan sangat tidak puas pada aspek kebijakan dan pada aspek penghargaan yang sebagian besar mengatakan sangat tidak puas. Ketidakpuasan perawat sebagian besar disebabkan oleh kebijakan yang diterapkan, kesempatan untuk mencoba metode-metode sendiri dalam melaksanakan pekerjaan dan penghargaan terhadap pekerjaan yang bagus.

\section{Hubungan Gaya Kepemimpinan} dengan Kepuasan Kerja Perawat Pelaksana

: Hasil penelitian terhadap 73 responden bahwa dari 41 perawat yang puas mayoritas mendapatkan penerapan gaya kepemimpinan secara demokratis sebanyak 25 responden $(34,2 \%)$ sedangkan dari 32 perawat yang tidak puas mayoritas mendapatkan penerapan gaya kepemimpinan yang otoriter sebanyak 20 responden $(27,4 \%)$. Setelah dilakukan analisa bivariat dengan menggunakan uji statistic chisquare diperoleh nilai $p$ value $=0,001$ ( $p$ $<0,05$ ) yang berarti ada hubungan gaya kepemimpinan dengan kepuasan kerja perawat pelaksana.

Hasil penelitian ini sesuai dengan penelitian yang dilakukan oleh Fahrurozi tentang hubungan gaya kepemimpinan kepala ruangan dengan kepuasan kerja perawat pelaksana di Puskesmas Langsa Lama. Hasil analisis bivariat menyimpulkan bahwa ada hubungan gaya kepemimpinan dengan kepuasan kerja perawat di Puskesmas Langsa Lama dengan nilai $\mathrm{p}=0,000^{(32)}$.

Hasil penelitian ini sesuai dengan penelitian yang dilakukan oleh Hilda, tentang hubungan gaya kepemimpinan, budaya organisasi dan imbalan dengan kepuasan kerja dan kinerja perawat pelaksana hasil penelitian menunjukkan bahwa ada hubungan gaya kepemimpinan dengan kepuasan kerja $(\mathrm{CR}=1,996, \mathrm{p}=0,042)^{(36)}$.

Hasil penelitian ini didukung oleh penelitian yang dilakukan oleh Maryati, tentang hubungan gaya kepemimpinan dan self efficacy dengan kepuasan kerja perawat di Puskesmas Kabupaten Majene yang menujukkan adanya hubungan yang bermakna antara gaya kepemimpinan dengan kepuasan kerja perawat $(p=0,003) .{ }^{(37)}$.

Kepemimpinan merupakan kemampuan memberi inspirasi kepada orang lain untuk bekerja sama sebagai suatu kelompok, agar dapat mencapai suatu tujuan umum. Gaya kepemimpinan adalah pola tingkah laku yang dirancang untuk mengintegrasikan tujuan organisasi dengan tujuan individu, untuk mencapai suatu tujuan (12).

Menurut Depkes RI, dalam Kurniadi, menyatakan bahwa seorang kepala ruangan memiliki tanggung jawab yaitu merencanakan kebutuhan tenaga perawat, merencanakan kebutuhan alat kesehatan dan penggunaannya, mengembangkan pelayanan keperawatan, melaksanakan penilaian kinerja perawat, memberikan orientasi kepada pasien baru, melaksanakan SAK (standar asuhan 
keperawatan dan standar SOP/Operasional Prosedur) yang ditetapkan pimpinan bidang keperawatan, melaksanakan pembimbingan mahasiswa keperawatan dan memberikan laporan berkala tentang pelayanan keperawatan $^{(14)}$.

Gaya kepemimpinan dalam mengarahkan, membina, berpartisipasi, dan mendukung bawahan dalam bekerja mampu memberikan kepuasan kerja dan meningkatan kinerja perawat pelaksana yang lebih baik dalam mencapai tujuan yaitu memberikan pelayanan keperawatan di Ruang Rawat Inap RSUD Kota Langsa, gaya kepemimpinan kepala ruang yang baik akan meningkatkan kepuasan kerja perawat, sehingga kalau kepemimpinan tersebut tidak baik maka akan menurunkan tingkat kepuasan kerja perawat. Diperlukan adanya peran dari pihak managerial untuk mempertahankan gaya kepemimpinan yang demokratis terutama dalam hal melibatkan diri dalam interaksi bersahabat dengan perawat pelaksana, tetapi terus berusaha memastikan bahwa semua anggota menyadari tanggung jawab dan standar pelayanan serta bersama-sama terlibat dalam pemecahan masalah dan memberikan pembinaan, pengembangan maupun seminar pada perawat dalam meningkatkan gaya kepemimpinan demokratis yang sesuai dengan standar prosedur pelayanan sehingga mampu meningkatkan kepuasan kerja perawat.

Peneliti berasumsi bahwa gaya
kepemimpinan kepala ruangan akan
berpengaruh dan berkaitan erat dengan kepuasan kerja yang dirasakan oleh perawat pelaksana. Hal ini sesuai dengan pendapat Kontesa, yang mengatakan bahwa penerapan gaya kepemimpinan yang tepat dapat memberikan pengaruh positif terhadap semangat kerja karyawan. Gaya kepemimpinan sebagai salah satu unsur yang penting didalam menjalankan kegiatan organisasi. Sebab gaya kepemimpinan merupakan perilaku pemimpin untuk mempengaruhi para pengikutnya. Oleh karena itu, kepribadian seseorang akan mempengaruhi gaya kepemimpinan yang digunakan.

\section{Hubungan Motivasi dengan Kepuasan Kerja Perawat Pelaksana :}

Hasil penelitian terhadap 73 responden bahwa dari 41 perawat yang puas mayoritas memiliki motivasi kerja positif sebanyak 38 responden $(52,1 \%)$ sedangkan dari 32 perawat yang tidak puas mayoritas memiliki motivasi kerja negatif sebanyak 29 responden (39,7\%). Setelah dilakukan analisa bivariat dengan menggunakan uji statistic chi-square diperoleh nilai $p$ value $=0,000(\mathrm{p}<0,05)$ yang berarti ada hubungan motivasi dengan kepuasan kerja perawat pelaksana.

Hasil penelitian yang dilakukan oleh Putri, Striatmi \& Fatmasari, mengenai faktorfaktor yang berhubungan dengan kepuasan kerja perawat rawat inap Rumah Sakit Umum Daerah Tugurejo Semarang yang menyimpulkan bahwa dan hubungan motivasi dengan kepuasan kerja perawat rawat inap RSUD Tugurejo Semarang (p value 0,000$)^{(7)}$. Sejalan dengan penelitian yang dilakukan oleh Kontesa mengenai hubungan 
gaya kepemimpinan kepala ruangan dengan motivasi kerja perawat di Ruang Rawat Inap Rumah Sakit Umum Dr. Rasidin Padang yang menyimpulkan bahwa ada hubungan motivasi kerja dengan kepuasan kerja perawat ${ }^{(5)}$.

Penelitian ini juga didukung oleh penelitian yang dilakukan oleh Indriono \& Zaenudin mengenai hubungan motivasi kerja perawat dengan kepuasan kerja perawat di Instalasi Rawat Inap Badan Rumah Sakit Umum Daerah Kabupaten Batang yang menyimpulkan bahwa ada hubungan motivasi kerja perawat dengan kepuasan kerja perawat dengan $p$-value $0,029(\mathrm{p}<0,05)^{(1)}$.

Motivasi adalah tindakan yang dilakukan ornag untuk memenuhi kebutuhan yang dilakukan ornag untuk memenuhi kebutuhan yang belum terpenuhi. Hal ini adalah keinginan untuk melakukan upaya mencapai tujuan atau penghargaan untuk mengurangi ketegangan yang disebabkan oleh kebutuhan tersebut.Motivasi instrinsik berasal dari dalam diri orang tersebut, yang mendorong dirinya menjadi produktif.Agar secara intrinsik dapat termotivasi dalam pekerjan, para pekerja harus menghargai performa dan produktivitas kerja ${ }^{(27)}$.

Motivasi intrinsik secara langsung berhubungan dengan tingkat ambisi seseorang. Orangtua dan teman sebaya berperan penting dalam pembentukan nilai seseorang mengenai apa yang ingin ia lakukan dan ingin menjadi apa. Orangtua yang menetapkan ekspektasi yang tinggi, tetapi dapat dicapai untuk anakanak mereka da yang secara terus-menerus mendorong mereka dalam lingkungan yang tidak otoriter cenderung memberikan dorongan pencapaian yangkuat pada anak-anak mereka. Latar belakang budaya juga mempunyai dampak terhadap motovasi intrinsik. Beberapa budaya menghargai mobilitas karir, keberhasilan kerja, dan pengakuan yang lebih dibandingkan dengan budaya lain ${ }^{(27)}$.

Motivasi ekstrinsik adalah motivasi yang ditingkatka oleh lingkungan kerja atau penghargaan eksternal.Penghargaan didapatka setelag pekerjaan selesai dilakukan.Meskipun semua orang secara intrinsik termotivasi sampai derajat tertentu, tidak realistis bagi organisasi untuk mengasumsikan bahwa semua pekerjaan mempunyai tingkat motivasi intrinsik yang memadai dalam mencapai tujuan organisasi.Oleh karena itu, organisasi harus menyediakan suasana yang merangsang motivasi, baik ekstrinsik maupun intrinsik ${ }^{(27)}$.

Peneliti berasumsi rendahnya kepuasan kerja perawat dihubungan dengan gaji yang diberikan dikarenakan tidak adanya pemberian insnetif tambahan atas suatu prestasi atau kerja ekstra hal ini akan memberikan dampak terhadap dedikasi perawat dalam memberikan pelayanan. Ketidakpuasan terhadap penghargaan yang diberikan ditunjukkan oleh sebagian besar perawat mengatakan bahwa pelaksanaan sistem upah belum sesuai dengan harapan. Kondisi ini yang menyebabkan menurunnya motivasi perawat dalam bekerja dan jika dibiarkan berlangsung terus akan mempunyai dampak negatif terhadap prestasi kerjanya. 


\section{Hubungan Supervisi dengan Kepuasan}

\section{Kerja Perawat Pelaksana :}

Hasil penelitian terhadap 73 responden bahwa dari 41 perawat yang puas mayoritas mendapatkan supervisi baik sebanyak 41 responden $(56,2 \%)$ sedangkan dari 32 perawat yang tidak puas mayoritas mendapatkan supervisi yang tidak baik sebanyak 23 responden $(31,5 \%)$ Setelah dilakukan analisa bivariat dengan menggunakan uji statistic $c h i-$ square diperoleh nilai $p$ value $=0,000(\mathrm{p}$ $<0,05)$ yang berarti ada hubungan supervisi dengan kepuasan kerja perawat pelaksana.

Hasil penelitian ini sejalan dengan penelitian yang dilakukan oleh Putri, Striatmi \& Fatmasari, mengenai faktor-faktor yang berhubungan dengan kepuasan kerja perawat rawat inap Rumah Sakit Umum Daerah Tugurejo Semarang yang menyimpulkan bahwa dan hubungan supervisi dengan kepuasan kerja perawat rawat inap RSUD Tugurejo Semarang (p value 0,000$)^{(7)}$.

Sejalan dengan penelitian yang dilakukan oleh Kontesa mengenai hubungan gaya kepemimpinan kepala ruangan dengan motivasi kerja perawat di Ruang Rawat Inap Rumah Sakit Umum Dr. Rasidin Padang yang menyimpulkan bahwa ada hubungan supervise dengan kepuasan kerja perawat ${ }^{(5)}$.

Penelitian ini juga didukung oleh penelitian yang dilakukan oleh Indriono \& Zaenudin mengenai hubungan motivasi kerja perawat dengan kepuasan kerja perawat di Instalasi Rawat Inap Badan Rumah Sakit Umum Daerah Kabupaten Batang yang menyimpulkan bahwa ada hubungan supervisi dengan kepuasan kerja perawat dengan p-value $0,029(\mathrm{p}<0,05)^{(1)}$.

Supervisi berasal dari kata super (bahasa latin yang bearti di atas) dan Videre (Bahasa latin yang bearti melihat). Bila dilihat dari asal kata aslinya, supervisi berarti melihat dari atas". Pengertian supervisi secara umum adalah melakukan pengamatan secara langsung dan berkala oleh "atasan" terhadap pekerjaan yang dilakukan "bawahan" untuk kemudian bila ditemukan masslah, segera diberikan bantuan yang bersifat langsung guna mengatasinya ${ }^{(23)}$.

Supervisi adalah proses pengamatan dari pelaksanaan seluruh kegiatan organisasi untuk menjamin agar semua pekerjaan yang sedang dilakukan berjalan sesuai dengan rencana yang telah ditetapkan. Sedangkan supervisi manajemen keperawatan merupakan salah satu jenis kegiatan pengamatan secara seksama sebagai sarana mengetahui kesalahan awal di semua lini untuk langsung diperbaiki atau dimodifikasi agar berjalan sesuai dengan ketentuan/pedoman pekerjaan yang telah disepakati bersama. Supervisi terhadap kegiatan organisasi dari level bawahan sampai atasan harus dilakukan setiap saat. Hal ini akan mempengaruhi semua karyawan bekerja pada standar/pedoman yang telah ditentukan (14).

Supervisi keperawatan adalah suatu proses pemberian sumber-sumber yang dibutuhkan perawat untuk menyelesaikan tugas dalam rangka mencapai tujuan. Supervisi sebagai suatu kegiatan pembinaan, bimbingan atau pengawasan oleh pengelola manajer) 
terhadap pelaksanaan dari tingkat yang rendah, menengah, atas dalam rangka menetapkan kegiatan sesuai dengan tujuan dan sasaran yang telah ditetapkan (17). Supervisi meliputi konsep supervisi, materi supervisi dan administrasi penunjang yang meliputi instrumen supervisi lengkap dengan parameter penilaian, laporan hasil kegiata supervisi serta pendokumentasian hasil supervisi (18).

Peneliti berasumsi bahwa supervisi merupakan bagian yang penting dalam kepuasan kerja perawat dan tidak dapat dipisahkan dalam pelayanan, hal ini dibuktikan dengan semakin sering melakukan supervisi maka berdampak pada kinerja perawat. Pengelolaan asuhan keperawatan membutuhkan kemampuan manajer keperawatan dalam melakukan supervisi. Kepala ruangan merupakan manajer garda depan dan penanggung jawab ruangan harus mampu menjadi supervisor yang baik terhadap perawat pelaksana dalam upaya meningkatkan kepuasan kerja. Adapun pelaksanaan supervisi yang belum maksimal adalah pada aspek kepala ruangan yang kurang memberikan pengarahan dan memotivasi perawat untuk asuhan keperawatan, kepala ruangan juga tidak memberikan penilaian yang objektif atas hasil kerja dalam melaksanakan asuhan keperawatan erta supervisi yang dilakukan tidak bersifat membimbing.

\section{Hubungan Beban Kerja dengan Kepuasan Kerja Perawat Pelaksana :}

Hasil penelitian terhadap 73 responden bahwa dari 41 perawat yang puas mayoritas memiliki lingkungan kerja yang baik sebanyak 39 responden $(53,4 \%)$ sedangkan dari 32 perawat yang tidak puas mayoritas memiliki lingkungan kerja yang kurang baik sebanyak 24 responden $(32,9 \%)$. Setelah dilakukan analisa bivariat dengan menggunakan uji statistic chi-square diperoleh nilai $p$ value $=$ $0,003$ ( $\mathrm{p}<0,05)$ yang berarti ada hubungan supervisi dengan kepuasan kerja perawat pelaksana.

Penelitian ini juga didukung oleh penelitian yang dilakukan oleh Indriono \& Zaenudin mengenai hubungan motivasi kerja perawat dengan kepuasan kerja perawat di Instalasi Rawat Inap Badan Rumah Sakit Umum Daerah Kabupaten Batang yang menyimpulkan bahwa ada hubungan lingkungan kerja perawat dengan kepuasan kerja perawat dengan $p$-value $0,029(\mathrm{p}<0,05)$ (1).

Hasil penelitian yang dilakukan oleh Wolo, Trsinawati \& Wiyadi mengenai faktorfaktor yang mempengaruhi kepuasan kerja perawat pada RSUD TNI AU Yogyakarta yang menunjukka bahwa yang memiliki pengaruh yang signifikan terhadap kepuasan kerja adalah faktor pekerjaan itu sendiri dan lingkungan kerja ${ }^{(3)}$.

Hasil penelitian yang dilakukan oleh Pratiwi mengenai hubungan lingkungan kerja dengan kepuasan kerja perawat pelaksana di Ruang Bangsal Rawat Inap Rsud Sunan Kalijaga Kabupaten Demak yang menunjukkan adanya pengaruh kualitas keperawatan $\quad(p=0,022 ; \quad \operatorname{Exp} \quad B=5,768)$, otonomi $\quad(p=0,020 ; \quad \operatorname{Exp} \quad \mathrm{B}=6,023) \quad$ dan 
DOI: http://dx.doi.org/10.35329/jkesmas.v6i1

pengembangan profesional $(p=0,002$; Exp $\mathrm{B}=$ 12,082) secara bersama-sama terhadap kepuasan kerja perawat pelaksana ${ }^{(8)}$.

Lingkungan kerja dalam suatu perusahaan sangat penting untuk di perhatikan manajemen. Meskipun lingkungan kerja tidak melaksanakan proses produksi dalam suatu perusahaan, namun lingkungan kerja mempunyai pengaruh lansung terhadap para karyawan yang melaksanakan proses produksi tersebut. Lingkungan kerja adalah suasana dimana karyawan melakukan aktivitas setiap harinya ${ }^{(28)}$

Lingkungan kerja adalah segala sesuatu yang ada disekitar karyawan dan dapat mempengaruhi dalam menjalankan tugas yang diembankan kepadanya misalnya dengan adanya air conditioner (AC), penerangan yang memadai dan sebagainya. Lingkungan kerja adalah sesuatu yang ada di lingkungan para pekerja yang dapat mempegaruhi dirinya dalam menjalankan tugas seperti temperatur, kelembapan, ventilasi, penerangan, kegaduhan, kebersihan tempat kerja dan memadai tidaknya alat-alat perlengkapan kerja. Menurut Simanjuntak lingkungan kerja dapat diartikan sebagai keseluruhan alat perkakas yang dihadapi, lingkungan sekitarnya dimana seorang bekerja, metode kerjanya, sebagai pengaruh kerjanya baik sebagai perorangan maupun sebagai kelompok.

Lingkungan kerja merupakan keadaan sekitar tempat kerja baik secara fisik maupun non fisik yang dapat memberikan kesan menyenangkan, mengamankan, menentramkan dan kesan betah bekerja dan lain sebagainya.
Sedarmayanti mendefinisikan lingkungan kerja merupakan keseluruhan alat perkakas dan bahan yang dihadapi, lingkungan sekitarnya dimana seseorang bekerja, metode kerjanya, serta pengaturan kerjanya baik sebagai perseorangan maupun kelompok. Dapat disimpulkan lingkungan kerja merupakan segala sesuatu yang berada di sekitar para karyawan yang dapat mempengaruhi dirinya dalam bekerja ${ }^{(28) .}$

Lingkungan kerja merupakan suatu dorongan yang menggerakan seseorang dalam hal ini karyawan untuk bekerja atau melakukan perbuatan tertentu. Perusahaan yang mampu memberdayakan karyawan lewat sumber daya manusia di dalam perusahaannya akan berhasil dalam mencapai tujuan-tujuan perusahaan. Namun untuk mencapai kinerja karyawan yang baik maka perusahaan harus mampu baik lewat sistem maupun lewat para pemimpin dan juga suasana di dalam organisasi untuk dapat mendorong karyawan untuk mencapai kinerja tertentu ${ }^{(29) \text {. }}$

Sihombing dalam Lidya menyatakan bahwa Lingkungan Kerja adalah faktor-faktor di luar manusia baik fisik maupun non fisik dalam suatu organisasi. Faktor fisik ini mencakup peralatan kerja, suhu tempat kerja, kesesakan dan kepadatan, kebisingan, luas ruang kerja sedangkan non fisik mencakup hubungan kerja yang terbentuk di instansi antara atasan dan bawahan serta antara sesama karyawan. Lingkungan kerja yang mendukung produktivitas kerja akan menimbulkan kepuasan kerja bagi pekerja dalam suatu organisasi. Menurut Sedarmayanti dalam 
Lidya menyatakan bahwa secara garis besar, jenis lingkungan kerja terbagi menjadi 2 yaitu Lingkungan Kerja Fisik dan Lingkungan Kerja Non Fisik. Lingkungan kerja yang kondusif memberikan rasa aman dan memungkinkan pegawai untuk dapat bekerja optimal. Lingkungan kerja dapat mempengaruhi emosional pegawai. Jika pegawai menyenangi lingkungan kerja di mana dia bekerja, maka pegawai tersebut akan betah di tempat kerjanya, melakukan aktivitasnya sehingga waktu kerja dipergunakan secara efektif. Produktivitas akan tinggi dan otomatis prestasi kerja pegawai juga tinggi (29).

Peneliti berasumsi bahwa lingkungan kerja merupakan salah satu aspek yang dapat mempengaruhi kepuasan kerja perawat, hal ini dikarenakan salah satu kendala dalam dalam melaksanakan asuhan keperawatan adalah sulitnya mengakses persediaan alat lainnya yang digunakan untuk melayani pasien. Dalam lingkungan kerja, setiap karyawan dituntut untuk dapat melaksanakan pekerjaan sesuai dengan jabatan yang dipegang dan beradaptasi dengan lingkungan serta rekan kerja yang memiliki karakter berbeda-beda. Interaksi antar individu dalam lingkungan kerja dapat menimbulkan dampak negatif yang memicu terjadinya konflik dan masalah dalam pekerjaan dan dampak positif yaitu terciptanya kondisi lingkungan kerja yang dinamis karena adanya penyesuaian terhadap tantangan dalam lingkungan internal organisasi dan eksternal karena pengaruh globalisasi, ledakan informasi melalui teknologi, obsesi kualitas, yang dapat menimbulkan terjadinya konflik di tempat kerja.

\section{KESIMPULAN}

Ada hubungan gaya kepemimpinan, motivasi kerja, supervisi dan lingkungan kerja dengan kepuasan kerja perawat pelaksana di Ruang Rawat Inap RSUD Langsa.

\section{DAFTAR PUSTAKA}

1. Cecep Triwibowo (2013). Manajemen Pelayanan Keperawatan di Rumah Sakit.Jakarta : Trans Info Media.

2. Creswel John, W. (2016). Pendekatan Metode Kualitatif, Kuantitaatif, dan Campuran. Yogyakarta: Pustaka Pelajar

3. Dewi Sandi. (2013). Gaya Kepemimpinan dan Budaya Organisasi Pengaruhnya Terhadap Kinerja Karyawan. Jurnal EMBA, Vol 1 No.3

4. Dharma. K.K. (2015). Metodologi Penelitian Keperawata. (Panduan Melaksanakan dan Menerapkan Hasil Penelitian. Jakarta : Trans Info Media.

5. Draft, Richard L. (2013). Manajemen. Jakarta: Erlangga.

6. Fattah.H. (2017).Kepuasan Kerja \& Kinerja Pegawai. Jakarta: Bimatera.

7. Gunawan. J. \& Sukarno. A. (2016). Potret Keperawatan di Belitung Indonesia. Tangerang : Yayasan Cipta Anak Bangsa.

8. Hamidah. S. Metodologi Penelitian Campuran (Mix Methode). Etheses.UIN.Malang.ac.id/1216/7/11/4101 38.

9. Indriono \& Zaenudin.(2016). Hubungan Antara Motivasi Kerja Perawat dengan Kepuasan Kerja Perawat di Instalasi Rawat Inap Badan Rumah Sakit Umum Daerah Kabupaten Batang.Prodi Ilmu Keperawatan FIK Universitas Pekalongan.

10. Kontesa, 2014. Hubungan Gaya Kepemimpinan Kepala Ruangan Dengan Motivasi Kerja Perawat di Ruang Rawat Inap Rumah Sakit Umum Daerah dr. Rasidin Padang. Program Studi D III Keperawatan STIKes MERCUBAKTIJAYA Padang. 
11. Kuncoro, A. (2014). Buku Ajar Menajemen Keperawatan.Yogyakarta : Nuha Medika.

12. Kurniadi.(2013). Manajemen Keperawatan dan Prospektifnya.Teori, Konsep dan Aplikasi.Jakarta : Fakultas Kedokteran Universitas Indonesia.

13. Lidya. (2015). Analisis Keterikatan Karyawan Terhadap Pekerjaan Dan Lingkungan Kerja Terhadap Kepuasan Kerja Dan Turnover Intentions Karyawan Di Rumah Sakit Siloam Manado. Jurnal EMBA, Vol 3 No.4.

14. Marquis \& Hutson. (2010). Kepemimpinan dan Manajemen Keperawatan.Jakarta : EGC.

15. Muhammad I. (2016). Panduan Penyusunan Karya Tulis Ilmiah Bidang Kesehatan Menggunakan Metode Ilmiah. Medan : Citapustaka Media Perintis.

16. Muhammad \& Lumitang.(2016). Pengaruh Lingkungan Kerja, Kompensasi dan Beban Kerja Terhadap Kinerja Karyawan Pada Dinas Pendapatan Daerah Kota Manado.Jurnal emba, Vol 4 No.1.

17. Noermijati.(2013). Aktualisasi Teori Herzberg Kepuasan Kerja dan Kinerja Spiritual Manajer Operasional.Jakarta : UB-Press.

18. Nursalam.(2016). Manajemen Keperawatan.Aplikasi dalam Praktik Keperawatan Profesional.Jakarta : Salemba Medika.

19. Pratiwi, (2015).Hubungan Lingkungan Kerja Dengan Kepuasan Kerja Perawat Pelaksana di Ruang Bangsal Rawat Inap Rsud Sunan Kalijaga Kabupaten Demak.

20. Putri, Sriatmi, Fatmasari. (2018). FaktorFaktor yang Berhubungan dengan Kepuasan Kerja Perawat Rawat Inap Rumah Sakit Umum Daerah Tugurejo Semarang. Jurnal Kesehatan Masyarakat (e-Journal) Volume 6, Nomor 4. http://ejournal3.undip.ac.id

21. Rahman. (2015). Pengaruh Kompetensi dan Lingkungan Kerja Terhadap Kinerja
Perawat Bagian Rawat Inap Pada Rumah Sakit Umum Daerah (RSUD) Petala Bumi Pekanbaru. Jurnal FEKON, Vol 2 No.1

22. Rahmi \& Kolibru. (2014). Faktor-Faktor Hygiene dan Motivator: Pengaruhnya terhadap Kepuasan Kerja Perawat di Rumah Sakit Baptis Batu. Jurnal Aplikasi Manajemen, Vol 12 No.4

23. Rifiani \& Sulihandari.(2013). PrinsipPrinsip Dasar Keperawatan. Cetakan I. Jakarta : Dunia Cerdas.

24. Rosyidi, K. (2013). Manajemen Kepemimpinan dalam Keperawatan. Jakarta: Trans Info Media.

25. Sandra \& Sondari.(2017). Faktor-Faktor Yang Berhubungan dengan Kepuasan Kerja Perawat Pelaksana di Ruang Rawat Inap RSUD Solok.Medisains. Jurnal Ilmiah Ilmu Kesehaan, Vol 5 No.3

26. Setiawan.(2015). Hubungan Gaya Kepemimpinan Demokratis Kepala Ruang Dengan Kepuasan Kerja Perawat di rumah sakit jiwa daerah Dr. Rm. Soedjarwadi.Program Studi S-1 Keperawatan Stikes Kusuma Husada Surakarta.

27. Setyowati. (2013). Organisasi dan Kepemimpinan. Jakarta : Graha Ilmu.

28. Sipatu. (2019). Pengaruh Motivasi, Lingkungan Kerja dan Strees Kerja Terhadap Kinerja Perawat di Ruang Rawat Inap RSUD Undata Palu. Jurnal Katalogis, Vol 1 No.1.

29. Suarli \& Bahtiar (2016). Manajemen Keperawatan. Jakarta. Erlangga.

30. Syahrir.(2013). Hubungan Supervisi dengan Pelaksanaan Asuhan Keperawatan di Ruang Rawat Inap RSUD Labuang Biji Makasar. Volume I Nomor 1, ISSN : 2302-2531. Library.stikesnh.ac.id

31. Tambunan.S.T. (2015).Pemimpin dan Kepemimpinan.Jakarta : Graha Ilmu. 